\title{
LEKSIKON ETNOMEDISIN DALAM PENGOBATAN TRADISIONAL SUKU DAYAK BAKUMPAI
}

\section{ETHNOMEDICIN LEXICON IN TRADITIONAL DAYAK BAKUMPAI TRIBAL MEDICINE}

\author{
Hestiyana \\ Balai Bahasa Kalimantan Selatan \\ hestiyana21@gmail.com
}

\begin{abstract}
ABSTRAK
Penelitian ini dilatarbelakangi adanya konsepsi suku Dayak Bakumpai terhadap pengobatan tradisional. Penelitian ini menganalisis leksikon etnomedisin dalam pengobatan tradisional suku Dayak Bakumpai. Tujuan penelitian ini adalah mendeskripsikan leksikon etnomedisin dan teknik peramuan dalam pengobatan tradisional suku Dayak Bakumpai. Metode yang digunakan dalam penelitian ini adalah metode deskriptif kualitatif. Data dalam penelitian ini berupa leksikonleksikon etnomedisin dalam pengobatan tradisional serta teknik peramuan dalam pengobatan tradisional suku Dayak Bakumpai yang diperoleh dari informan di Kabupaten Barito Kuala, Kalimantan Selatan. Teknik pengumpulan data yang digunakan adalah metode simak, catat, dan studi kepustakaan. Instrumen penelitian ini adalah peneliti sendiri sebagai observer dan lembar observasi. Analisis data mencakup pengklasifikasian leksikon etnomedisin berdasarkan jenis-jenis tumbuhan obat dan fungsinya serta teknik peramuan dalam pengobatan tradisional suku Dayak Bakumpai. Kemudian, mendeskripsian, menganalisis, mentranskripsikan, menginterpretasikan, dan menyimpulkan hasil penelitian. Dari hasil analisis leksikon etnomedisin dalam pengobatan tradisional suku Dayak Bakumpai ditemukan 40 leksikon etnomedisin dalam pengobatan tradisional suku Dayak Bakumpai berdasarkan jenis-jenis tumbuhan obat dan fungsinya. Kemudian, bagian tumbuhan yang digunakan untuk pengobatan, yakni akar, umbi (rimpang), batang, daun, pucuk, dan bagian kulit tumbuhan. Selanjutnya, teknik peramuan dalam pengobatan tradisional suku Dayak Bakumpai dilakukan dengan cara diminum, dioles, diusap, ditempel, diuapkan, dan disiram ke bagian tubuh (mandi).
\end{abstract}

Kata kunci: leksikon etnomedisin, pengobatan tradisional, Dayak Bakumpai

\begin{abstract}
This research is based on the conception of the Dayak Bakumpai tribe towards traditional medicine. This study analyzed ethnomedical lexicons in traditional Dayak Bakumpai tribal medicine. The purpose of this study is to describe the ethnomedicin lexicon and the techniques of composition in the traditional treatment of the Dayak Bakumpai tribe. The method used in this study is qualitative descriptive method. The data in this study were ethnomedicin lexicons in traditional medicine and the techniques of composition in traditional medicine of the Dayak Bakumpai tribe obtained from informants in Barito Kuala Regency, South Kalimantan. Data collection techniques used are the method of referencing,
\end{abstract}


Tuah Talino

Tahun XIII Volume 13 Nomor 1 Edisi 5 Juli 2019

ISSN 0216-079X

Balai Bahasa Kalimantan Barat

note taking, and library research. The instrument of this study was the researcher as observer and observation sheets. Data analysis includes the classification of ethnomedicin lexicon based on the types of medicinal plants and their functions and the techniques of composition in the traditional treatment of the Dayak Bakumpai tribe. Then, describe, analyze, transcribe, interpret, and conclude the results of the study. From the results of the ethnomedicin lexicon analysis in traditional Dayak Bakumpai tribal medicine, 40 ethnomedicin lexicons were found in traditional Dayak Bakumpai tribal medicine based on the types of medicinal plants and their functions. Then, plant parts are used for medicine, namely roots, tubers (rhizomes), stems, leaves, shoots, and parts of plant skin. Furthermore, the techniques of composition in the traditional treatment of the Dayak Bakumpai tribe are carried out by drinking, smearing, rubbing, sticking, evaporating, and watering to the body part (bathing).

Keywords: ethnomedicine lexicon, traditional medicine, Bakumpai Dayak

\section{PENDAHULUAN}

Bahasa merupakan alat untuk mengungkapkan dan menyampaikan berbagai informasi atau pesan. Salah satunya, bahasa digunakan sebagai sarana menyampaikan warisan budaya secara turun temurun tentang pengobatan tradisional. Sistem pengobatan tradisional sampai saat ini masih tetap ada, meskipun praktik-praktik pengobatan medis juga sudah berkembang pesat.

Tumbuhan memiliki berbagai macam manfaat dan salah satunya adalah sebagai obat-obatan. Setiap daerah memiliki karakteristik dan pemanfaatan tumbuhan sebagai obat-obatan. Tumbuhan yang diprediksi memiliki khasiat mengatasi sakit dan penyakit sering kali dimanfaatkan oleh berbagai kelompok masyarakat, khususnya kelompok suku-suku di wilayah pedalaman Kalimantan Selatan. Suku Dayak Bakumpai merupakan salah satu suku yang masih memanfaatkan tumbuhan berkhasiat obat sebagai alternatif pengobatan medis.

Penggunaan ramuan obat tradisional Indonesia telah dilakukan oleh nenek moyang kita sejak zaman dahulu, penggunaan obat bahan alam atau yang lebih dikenal dengan sebutan obat tradisional merupakan bagian dari budaya bangsa dan telah dimanfaatkan oleh masyarakat sejak berabad-abad yang lalu. Obat tradisional berkembang diawali dengan pengalaman pengobatan terhadap diri sendiri dan kemudian ditularkan kepada orang lain dan generasi selanjutnya. Indonesia memiliki sekitar 400 suku bangsa/etnis yang memiliki peradaban dan pengetahuan yang diwariskan dari generasi ke generasi, termasuk budaya penggunaan obat-obat tradisional dalam pengobatan (Wasito, 2011: 9). Hal yang sama juga diungkapkan Siti dalam Fitri, dkk., (2018: 309) bahwa penggunaan tumbuhan untuk memenuhi kebutuhan umat manusia dalam bidang pengobatan adalah suatu seni yang sama tuanya dengan sejarah peradaban umat manusia.

Pengobatan tradisional sangat banyak dilakukan di pelosok-pelosok desa. Alternatif pengobatan yang praktis dan murah serta alami diyakini menjadi suatu pengobatan yang efektif sehingga obat-obatan tersebut tetap digunakan oleh masyarakat sebagai alternatif pengobatan sebelum ke puskesmas ataupun ke dokter. Hal ini seperti yang dikemukakan Humaedi (2016: 6) bahwa gabungan antara pengetahuan etnik terhadap obat dan ketersediaan sumber bahan alami, 
khususnya yang berasal dari hutan tropika telah menjadikan praktik pengobatan etnik mendapatkan tempat tersendiri di tengah pengobatan modern. Praktik pengobatan ini bahkan dapat menjadi rujukan utama atau sebaliknya menjadi salah satu bahan inovasi dari pengobatan modern.

Pendapat yang sama dikemukakan Syamsiah dalam Fitri, dkk., (2018: 307) bahwa tumbuhan obat ini tersebar luas di wilayah pelosok negeri dan dimanfaatkan sebagai pengobatan alternatif masyarakat. Obat tradisional (obat herbal) banyak digunakan masyarakat menengah ke bawah terutama dalam upaya pencegahan penyakit (preventif), penyembuhan (kuratif), pemulihan kesehatan (rehabilitatif), serta peningkatan kesehatan (promotif).

Suparni (2013: 6) menjelaskan manfaat tumbuhan obat dalam pengobatan dan faktor yang menjadi alasan masyarakat modern kembali menggunakan tumbuhan obat dan pengobatan herbal sebagai berikut: (1) harga obat-obatan kimia semakin mahal yang tidak terjangkau oleh semua masyarakat; (2) efek samping yang ditimbulkan oleh pengobatan tradisional hampir tidak ada; (3) obatobatan kimiawi sebenarnya dibuat secara sintetis berdasarkan obat-obatan alami, tapi karena obat-obatan alami belum mendapatkan standarisasi secara medis, akhirnya digunakan obat-obatan kimiawi; (4) pengobatan dengan cara herbal lebih mudah dilakukan dan biasanya bahan-bahannya sangat mudah didapatkan di sekitar kita; (5) adanya keyakinan empiris bahwa pengobatan herbal lebih aman di kalangan masyarakat berdasarkan pengalaman dari leluhur dan orang-orang yang menggunakan pengobatan herbal; (6) pembuatan pengobatan herbal yang telah dibentuk dalam pil atau kapsul, cairan, dan dikemas modern membuat orang lebih memilih pengobatan herbal daripada pengobatan kimia.

Mengingat banyaknya manfaat yang didapat dari tumbuh-tumbuhan bagi kesehatan sehingga salah satu upaya yang harus dilakukan untuk melestarikannya, yakni dengan melakukan kajian ini. Pemanfaatan tumbuhan obat di setiap daerah memiliki cara penggunaan berbeda-beda. Suku Dayak Bakumpai memiliki budaya pengobatan tradisional tumbuhan berkhasiat obat yang diwariskan secara turun temurun dan masih digunakan hingga saat ini.

Pada era modern sekarang ini sulit kita temukan penggunaan leksikon pengobatan tradisional dalam bahasa daerah. Hal ini menyebabkan berkurangnya jumlah kosakata daerah. Sistem pengobatan tradisional pun lebih banyak diketahui secara lisan. Hal ini lama-kelamaan akan menyebabkan hilangnya warisan pengobatan tradisional apabila tidak dilakukan pendokumentasian. Apalagi, generasi penerus sekarang banyak yang tidak mengetahui sistem pengobatan tradisional karena lebih cenderung pada pengobatan modern. Menarik untuk dikaji, sejauh mana penggunaan leksikon etnomedisin yang digunakan suku Dayak Bakumpai. Dengan demikian, perlu dilakukan penelitian agar generasi sekarang dapat mengetahui dan ikut melestarikan warisan budaya sistem pengobatan tradisional.

Penelitian yang relevan dengan penelitian ini, yakni penelitian yang dilakukan Almos dan Pramono (2015) dengan judul "Leksikon Etnomedisin dalam Pengobatan Tradisional Minangkabau". Dari hasil penelitiannya ditemukan bahwa leksikon pengobatan tradisional Minangkabau dapat dikelompokkan menjadi tiga, yaitu: (1) jenis-jenis penyakit, (2) jenis-jenis ramuan, dan (3) 
leksikon lainnya. Pada kelompok jenis-jenis penyakit, contoh leksikon yang ditemukan biriang, tinggam, dan sijundai. Kelompok jenis-jenis ramuan leksikon yang digunakan, di antaranya limau, injuang, ayam, air, dan batu. Pada kelompok terakhir, yakni proses pengobatan ditemukan leksikon manyilau dan paureh.

Penelitian yang terkait dengan leksikon etnomedisin juga pernah dilakukan Hestiyana (2017) dengan judul "Leksikon dalam Tuturan Mantra Panawar (Kajian Etnomedisin sebagai Alternatif Pengobatan Tradisional Masyarakat Banjar)." Hestiyana dalam penelitiannya menemukan deskripsi dan klasifikasi leksikon yang terdiri dari leksikon berdasarkan bahan pengobatan tradisional, alat pengobatan, dan kegiatan pengobatan. Sementara itu, pada mantra terdapat makna bahwa penyakit yang datang berasal dari roh jahat seperti setan atau jin, obat yang ditawari dengan mantra atau doa digunakan dalam proses penyembuhan dan penyakit dapat disembuhkan atas izin Allah melalui keberkatan kalimat syahadat Lailahailallah.

Penelitian yang terkait dengan leksikon pengobatan tradisional juga dilakukan Aisyah, dkk. (2018) yang berjudul "Leksikon Nama Penyakit dan Pengobatan Tradisional dalam Bahasa Melayu Dialek Pontianak di Kecamatan Kubu." Berdasarkan penelitiannya ditemukan 84 leksikon nama penyakit dan pengobatan tradisional yang terdiri dari tiga bentuk leksikon, yakni monomorfemis (kata tunggal) sebanyak 46 leksikon dan polimorfemis (kata turunan) sebanyak 38 leksikon. Leksikon nama penyakit dan pengobatan tradisonal tersebut secara keseluruhan memiliki arti leksikal dan arti kultural nama penyakit sebanyak 24 leksikon dan menghasilkan suplemen bahan teks pembelajaran Bahasa Indonesia kurikulum 2013 berupa teks deskripsi dan prosedur.

Berbeda dengan penelitian sebelumnya, fokus penelitian ini adalah leksikon etnomedisin dalam pengobatan tradisional suku Dayak Bakumpai. Sebagian besar kehidupan suku Dayak Bakumpai masih akrab dengan alam sehingga sejak dulu sudah memanfaatkan tumbuhan obat. Penggunaan tumbuhan obat secara tradisional ini dilakukan secara turun temurun. Masyarakat suku Dayak Bakumpai masih ada yang mempercayai pengobatan tradisional serta pengolahannya masih sederhana dan berdasarkan resep para leluhurnya. Warisan leluhur berupa sistem pengobatan tradisional ini perlu didokumentasikan agar tidak punah dan hilang begitu saja.

Berdasarkan uraian terdahulu, masalah dalam penelitian ini, yaitu: (1) bagaimana leksikon etnomedisin dalam pengobatan tradisional suku Dayak Bakumpai? dan (2) bagaimana teknik peramuan dalam pengobatan tradisional suku Dayak Bakumpai? Penelitian ini bertujuan, antara lain: (1) mendeskripsikan leksikon etnomedisin dalam pengobatan tradisional suku Dayak Bakumpai dan (2) mendeskripsikan teknik peramuan dalam pengobatan tradisional suku Dayak Bakumpai.

Manfaat yang ingin diperoleh dari hasil penelitian ini, yakni dapat memberikan informasi kepada masyarakat luar mengenai leksikon etnomedisin dalam pengobatan tradisional suku Dayak Bakumpai serta menambah khasanah kekayaan tumbuhan berkhasiat obat dan cara pengobatannya. 
Ada dua konsep yang penting untuk dijelaskan dalam penelitian ini, yakni leksikon dan etnomedisin. Chaer (2007: 5) mengatakan bahwa istilah leksikon berasal dari kata Yunani kuno lexicon yang berarti 'kata', 'ucapan', atau 'acara berbicara'. Kata leksikon seperti ini sekerabat dengan kata leksem, leksikografi, leksikograf, dan leksikal. Lebih lanjut Chaer (2007: 2) menyatakan bahwa istilah leksikon lazim digunakan untuk mewadahi konsep kumpulan leksem dari satu bahasa, baik kumpulan secara keseluruhan maupun secara sebagian.

Wijana (2015: 29) menyatakan bahwa leksem adalah satuan bahasa yang memiliki kemampuan untuk mengacu dan memprediksi. Selanjutnya, leksikon bahasa adalah kumpulan leksem yang dimiliki oleh sebuah bahasa (Wijana, 2015: 30).

Spencer dalam Suktiningsih (2016:139) menyatakan bahwa the term lexicon means simply dictionary is a list of words together with their meaning and other useful bits of linguistic information. Pernyataan tersebut mengisyaratkan bahwa leksikon adalah daftar kata yang mengandung makna yang sedikit disertai dengan keterangan-keterangan yang berkaitan dengan informasi linguistik.

Elson \& Picket dalam Suktiningsih (2016:139) mendefinisikan leksikon sebagai kosakata suatu bahasa atau kosakata yang dimiliki oleh seorang penutur bahasa atau seluruh jumlah morfem atau kata-kata sebuah bahasa.

Dengan demikian, leksikon merupakan kosakata suatu bahasa atau kumpulan leksem baik secara keseluruhan maupun secara sebagian yang dimiliki oleh sebuah bahasa dan memiliki relasi makna dengan sesuatu di luar bahasa serta merupakan kombinasi antara bentuk dan makna. Kajian ini menggunakan pemahaman tentang teori leksikon yang dikemukakan Chaer (2007).

Selanjutnya, etnomedisin secara etimologi berasal dari kata ethno (etnis) dan medicine (obat). Hal ini menunjukkan bahwa etnomedisin sedikitnya berhubungan dengan dua hal, yakni etnis dan obat. Etnomedisin merupakan kepercayaan dan praktik-praktik yang berkenaan dengan penyakit yang merupakan hasil perkembangan kebudayaan asli dan tidak berasal dari kerangka konseptual kedokteran modern (Foster dan Barbara, 2015: 6).

Pengetahuan etnomedisin adalah pengetahuan tentang pengembangan pengobatan yang didasarkan atas makna budaya lokal dengan strategi integrasi antara kepercayaan dan praktek pengobatan terhadap penyakit tertentu yang tidak dipengaruhi oleh kerangka obat modern sehingga pengetahuan etnomedisin pada setiap etnis adalah unik (Sumawardani dalam Wulandari, 2018: 1).

Di bidang antropologi kesehatan, etnomedisin memunculkan terminologi yang beragam. Cabang ini sering disebut pengobatan tradisional, pengobatan primitif, tetapi etnomedisin terasa lebih netral (Foster\& Barbara, 2015: 62).

Pengertian sakit dijelaskan Perkins dalam Mulyanti (2016: 4) bahwa sakit adalah tidak menyenangkan yang menimpa seseorang sehingga menimbulkan gangguan dalam aktivitas sehari-hari, baik aktivitas jasmani, rohani, maupun sosial. Keadaan sakit sering digunakan untuk menilai tingkat kesehatan suatu masyarakat. Keadaan sakit merupakan akibat dari kesalahan adaptasi terhadap lingkungan (maladaptation) serta reaksi antara manusia dan sumber-sumber penyakit. 
Penyakit adalah pengakuan sosial bahwa seseorang itu tidak bisa menjalankan peran normalnya secara wajar dan harus dilakukan sesuatu terhadap situasi tersebut. Penyakit juga merupakan sesuatu yang datang dari Tuhan, ada yang dapat dilihat dari benda nyata, tetapi ada pula penyakit yang tidak diketahui penyebabnya atau datang secara gaib (Foster dan Barbara, 2015: 50). Hal yang sama dikemukakan Humaedi (2016: 7) bahwa praktik pengobatan kerap mencakup di dalamnya praktik ritual kepercayaan. Aspek ritual menjadi bagian terpenting proses pengobatan karena menegaskan ketundukan terhadap sesuatu yang transenden, sesuatu Yang Suci.

Foster dan Barbara (2015: 63) menjelaskan bahwa menurut kerangka etnomedisin, penyakit dapat disebabkan dua faktor, antara lain: pertama, pandangan personalistik, yakni penyakit yang disebabkan oleh agen (tokoh) seperti dewa, lelembut, makhluk halus, manusia, dan sebagainya yang pengobatannya menggunakan bahan-bahan dari tumbuhan (herbalmedicine) dan hewan (animalmedicine) atau keduanya. Kedua, pandangan nonsupranatural, yakni penyakit yang disebabkan karena terganggunya keseimbangan tubuh karena unsur-unsur tetap dalam tubuh seperti panas dingin dan sebagainya yang pengobatannya menggunakan ritual dan magis.

Penyakit itu sendiri dapat disembuhkan dengan ramuan obat yang berasal dari tumbuh-tumbuhan. Hal ini seperti yang dinyatakan Sumawardani (dalam Wulandari, 2018: 18) bahwa ramuan obat tradisional adalah media pengobatan alamiah dengan memakai tumbuhan sebagai bahan dasarnya, jenis tumbuhan yang berkhasiat obat sebenarnya banyak dan dapat diperoleh di lingkungan sekitar, seperti di halaman rumah, pinggir jalan, dan di dapur sebagai bahan atau bumbu masak.

Pendapat yang relevan juga dikemukakan Nurkosim (2009: 19) bahwa setiap tumbuhan memiliki khasiat yang beragam dan dapat mengobati lebih dari satu jenis penyakit. Hal ini disebabkan oleh kandungan zat aktif dari tumbuhan tersebut, jenis, dan ragamnya yang banyak. Setiap zat aktif memiliki khasiat tertentu, mengobati dan memperbaiki sel-sel tubuh dari jaringan dan organ tertentu. Setiap zat aktif yang terkandung dalam satu jenis tumbuhan, satu sama lain bekerja secara sinergis dan saling meniadaan efek samping. Selain memiliki banyak khasiat, setiap tumbuhan juga memiliki khasiat yang utama yang paling dominan terhadap jenis penyakit tertentu yang dapat dibedakan antara satu dengan yang lainnya.

Purwanto (2002: 96) menyatakan pentingnya etnomedisin bagi pengobatan merupakan salah satu cara mengembangkan pengobatan dan pengetahuan obat dalam memenuhi kebutuhan dasar di bidang kesehatan serta merupakan cara yang efektif dalam menemukan bahan-bahan kimia yang berguna dalam pembuatan obat yang memiliki efek samping lebih kecil, timbulnya efek resisten dari obat yang sudah ada dan juga untuk antisipasi munculnya penyakit baru.

Dengan demikian, etnomedisin merupakan subdisiplin ilmu dari antropologi kesehatan yang kajiannya mengenai pengobatan-pengobatan pada masyarakat tradisional. Pengobatan tradisional merupakan suatu upaya penyembuhan dengan cara yang tradisional, berakar menjadi tradisi, kepercayaan, dan praktik pengobatan terhadap penyakit tertentu. Pengetahuan mengenai leksikon 
etnomedisin merupakan pengetahuan mengenai konteks kata, daftar kata yang memuat tentang makna yang terkait dengan tumbuhan obat. Dengan kata lain, leksikon etnomedisin merupakan kosakata tumbuhan yang memiliki khasiat yang beragam dan dapat mengobati lebih dari satu jenis penyakit.

\section{METODE}

Penelitian ini menggunakan metode deskriptif kualitatif. Djajasudarma (2010: 9) menyatakan bahwa metode deskriptif adalah metode yang bertujuan untuk membuat deskripsi, maksudnya membuat gambaran, lukisan secara sistematis, faktual, dan akurat mengenai data, sifat-sifat, serta hubungan fenomena-fenomena yang diteliti.

Kemudian, Sugiyono (2014: 1) mengemukakan bahwa penelitian kualitatif adalah metode penelitian yang digunakan untuk meneliti objek yang dialami, di mana peneliti adalah instrumen kunci, teknik pengumpulan data dilakukan secara trianggulasi (gabungan), analisis data bersifat induktif, dan hasil penelitian kualitatif lebih menekankan makna daripada generalisasi.

Data dalam penelitian ini berupa leksikon-leksikon etnomedisin dalam pengobatan tradisional serta cara pengobatan tradisional suku Dayak Bakumpai yang diperoleh dari tatuha adat dan balian di Kabupaten Barito Kuala, Kalimantan Selatan. Teknik pengumpulan data yang digunakan adalah metode simak dan metode catat. Sudaryanto (2015: 203) mengemukakan bahwa metode simak atau penyimakan dilakukan dengan menyimak, yaitu menyimak penggunaan bahasa. Setelah melakukan penyimakan baris demi baris, teknik yang digunakan selanjutnya adalah teknik catat. Mahsun (2013: 93) menyatakan bahwa teknik catat merupakan teknik lanjutan yang dilakukan ketika menerapkan metode simak dengan teknik lanjutan.

Metode pengumpulan data juga dilakukan dengan studi kepustakaan, yakni dengan mempelajari berbagai literatur yang berkaitan dengan objek penelitian. Instrumen penelitian ini adalah peneliti sendiri sebagai observer dan lembar observasi. Adapun analisis data mencakup pengklasifikasian leksikon etnomedisin berdasarkan jenis-jenis tumbuhan obat dan fungsinya serta cara pengobatan tradisional suku Dayak Bakumpai. Kemudian, mendeskripsian, menganalisis, mentranskripsikan, dan menginterpretasikan hasil penelitian. Selanjutnya menyimpulkan hasil penelitian.

\section{PEMBAHASAN}

\section{Suku Dayak Bakumpai dan Tradisi Pengobatannya}

Suku Dayak Bakumpai merupakan salah satu suku di Kalimantan Selatan yang memanfaatkan tumbuhan sebagai pengobatan tradisional. Suku Dayak Bakumpai memiliki pengetahuan pengobatan tradisional tersebut secara lisan dan diwariskan secara turun temurun. Pemanfaatan tumbuhan obat yang masih digunakan suku Dayak Bakumpai biasanya dilakukan oleh tatuha adat atau balian yang memang sudah berpengalaman dalam proses pengobatan tradisional. Balian merupakan orang yang secara turun temurun mendapat warisan dari balian tuha atau secara legitimasi keharusan seseorang menjadi balian. 
Tuah Talino

Tahun XIII Volume 13 Nomor 1 Edisi 5 Juli 2019

ISSN 0216-079X

Balai Bahasa Kalimantan Barat

Dalam proses pengobatan pun akan dilakukan beberapa ritual. Akan tetapi, fokus penelitian hanya menganalisis leksikon etnomedisin dalam pengobatan tradisional suku Dayak Bakumpai berdasarkan jenis-jenis tumbuhan obat dan fungsinya serta teknik peramuan dan nilai pengetahuannya.

\section{Leksikon Tumbuhan Obat dalam Pengobatan Tradisional Suku Dayak Bakumpai}

Berdasarkan hasil analisis ditemukan 40 leksikon jenis tumbuhan obat yang digunakan suku Dayak Bakumpai. Berikut tabel yang menunjukkan leksikon jenis tumbuhan obat berdasarkan fungsi dan manfaatnya.

Tabel 1

Leksikon Tumbuhan Obat Berdasarkan Fungsi dan Manfaat

\begin{tabular}{|c|c|c|c|}
\hline No & Nama Tumbuhan & Nama Ilmiah & Fungsi atau Manfaat \\
\hline 1 & Akar kuning & Coscinium fenestratum & mengobati penyakit kuning \\
\hline 2 & Akar melati & Jasminum sambac & mengobati impoten \\
\hline 3 & Akar pudak & $\begin{array}{l}\text { Pandanus } \\
\text { amaryllifoliusRoxb }\end{array}$ & mengobati sakit lutut \\
\hline 4 & Belimbing tunjuk & averrhoa bilimbi $L$ & mengobati kencing manis \\
\hline 5 & Bingkudu hutan & $\begin{array}{l}\text { fagraea racemosa jack } \\
\text { ex Wall }\end{array}$ & mengobati stroke \\
\hline 6 & Hambin buah & $\begin{array}{l}\text { phyllanthus urinaria } \\
\text { Linn }\end{array}$ & daya tahan tubuh \\
\hline 7 & Hapa-hapa & flemingiamacrophylla & mengobati kanker \\
\hline 8 & Hara & $\begin{array}{l}\text { ficus racemosa } L \\
\text { (Moraceae }\end{array}$ & $\begin{array}{lc}\text { mempermudah } \\
\text { melahirkan }\end{array}$ \\
\hline 9 & Jajuluk langit & $\begin{array}{l}\text { helminthostachys } \\
\text { zeylanica }\end{array}$ & mengobati sakit pinggang \\
\hline 10 & Janar kuning & curcumadomestica Val & mengobati kanker dalam tubuh \\
\hline 11 & Janar putih & keampferia rotunda $L$ & mengobati paru-paru \\
\hline 12 & Kakabat biru & $\begin{array}{ll}\text { justicia } & \text { gendarussa } \\
\text { Burm.f } & \\
\end{array}$ & mengobati bengkak hati \\
\hline 13 & Karamunting & $\begin{array}{l}\text { rhodomyrtus tomentosa } \\
\text { (aiton hassk) }\end{array}$ & mengobati tekanan darah tinggi \\
\hline 14 & Kayu baru & hibiscus tiliaceus L & mengobati kanker kista \\
\hline 15 & Kayи muhur & lagerstromia speciosa & mengobati disentri \\
\hline 16 & Kecabling & $\begin{array}{l}\text { clerodendron } \\
\text { calamitosum } L \\
\end{array}$ & mengobati kencing manis \\
\hline 17 & Kratau & morus alba $L$ & $\begin{array}{l}\text { mempermudah } \\
\text { melahirkan }\end{array}$ \\
\hline 18 & Kujajing & & $\begin{array}{lc}\text { mempermudah } & \text { proses } \\
\text { melahirkan } & \end{array}$ \\
\hline 19 & Kumis kucing & orthosiphon aristatus & mengobati kencing manis \\
\hline 20 & Kusuma indrat & euphorbia hirta $L$ & mengobati mencret anak-anak \\
\hline 21 & Langsat & $\begin{array}{l}\text { lansium domesticum } \\
\text { Corr var duku Hasskl }\end{array}$ & untuk mengobati obat diare \\
\hline 22 & Laus & alpinia galagal & mengobati stroke \\
\hline 23 & Mambung & blumea balsamifera & mengobati kanker \\
\hline
\end{tabular}


Tuah Talino

Tahun XIII Volume 13 Nomor 1 Edisi 5 Juli 2019

ISSN 0216-079X

Balai Bahasa Kalimantan Barat

\begin{tabular}{|c|c|c|c|}
\hline & & (L.) $D C$ & \\
\hline 24 & Panawar seribu & euphorbia tirucalli $L$ & mengobati sakit struk \\
\hline 25 & Papulut & urena lobata Linn & mengobati sakit gigi \\
\hline 26 & Pasak bumi & eurycoma longifolia & $\begin{array}{l}\text { mengobati sakit pinggang dan } \\
\text { menyegarkan badan }\end{array}$ \\
\hline 27 & Patah kemudi & codiaeum variegatum & mengobati sakit keseleo \\
\hline 28 & Pikis bidadari & $\begin{array}{l}\text { drymoglossum } \\
\text { piloselloides }\end{array}$ & $\begin{array}{l}\text { membersihkan muka atau } \\
\text { menghilangkan jerawat }\end{array}$ \\
\hline 29 & Pirawas & & $\begin{array}{l}\text { perawatan setelah melahirkan } \\
\text { atau melangsingkan badan }\end{array}$ \\
\hline 30 & Pucuk putat & $\begin{array}{l}\text { barringtonia } \\
\text { acuatangula } L\end{array}$ & mengobati gatal-gatal \\
\hline 31 & Rotan nyame & $\begin{array}{l}\text { bromheadia finlaysonia } \\
\text { (Lind) Miq }\end{array}$ & reproduksi pria \\
\hline 32 & Sabambelum & $\begin{array}{l}\text { kalanchoe pinnata } \\
\text { Lamk }\end{array}$ & $\begin{array}{l}\text { mengobati sakit panas anak- } \\
\text { anak }\end{array}$ \\
\hline 33 & Sangkariho & $\begin{array}{l}\text { callicarpa longifolia } \\
\text { Lam }\end{array}$ & $\begin{array}{l}\text { perawatan setelah melahirkan } \\
\text { dan obat dalam tubuh }\end{array}$ \\
\hline 34 & Sarai & $\begin{array}{l}\text { cymbopogon citratus } \\
(D C)\end{array}$ & $\begin{array}{l}\text { mengobati sakit stroke ringan } \\
\text { atau kram }\end{array}$ \\
\hline 35 & Sirih & piper betle $L$ & $\begin{array}{l}\text { mengobati keputihan, } \\
\text { menghentikan pendarahan, dan } \\
\text { menghilangkan bau badan }\end{array}$ \\
\hline 36 & Sungkai & $\begin{array}{l}\text { albertisia papuana } \\
\text { Becc }\end{array}$ & mengobati sakit pinggang \\
\hline 37 & Tambura & ageratum conyzoides $L$ & perawatan setelah melahirkan \\
\hline 38 & Tangkuhis & $\begin{array}{l}\text { dimocarpus malesianus } \\
\text { Leenh }\end{array}$ & mengobati sakit diare \\
\hline 39 & Tingen & imperata cylindrica $L$ & $\begin{array}{l}\text { mengobati sakit kencing manis } \\
\text { dan radang ginjal }\end{array}$ \\
\hline 40 & Tuntung uhat & & mengobati luka \\
\hline
\end{tabular}

Dari 40 leksikon jenis tumbuhan obat yang digunakan suku Dayak Bakumpai dapat diklasifikasikan lagi menjadi 6 bagian, yakni tumbuhan obat berdasarkan, yaitu: (1) bagian akar yang dimanfaatkan, (2) bagian batang yang dimanfaatkan, (3) bagian daun yang dimanfaatkan, (4) bagian kulit kayu yang dimanfaatkan, (5) bagian umbi atau rimpang yang dimanfaatkan, dan (6) bagian pucuk daun yang dimanfaatkan. Hal ini dapat dilihat pada tabel berikut.

Tabel 2

Leksikon Tumbuhan Obat Berdasarkan Bagian Akar yang Dimanfaatkan

\begin{tabular}{|c|l|c|}
\hline No & \multicolumn{1}{|c|}{ Nama Tumbuhan } & Bagian yang Dimanfaatkan \\
\hline 1 & Akar melati & Akar \\
\hline 2 & Akar pudak & Akar \\
\hline 3 & Belimbing tunjuk & Akar \\
\hline 4 & Hapa-hapa & Akar \\
\hline 5 & Hara & Akar \\
\hline 6 & Jajuluk langit & Akar \\
\hline
\end{tabular}


Tuah Talino

Tahun XIII Volume 13 Nomor 1 Edisi 5 Juli 2019

ISSN 0216-079X

Balai Bahasa Kalimantan Barat

\begin{tabular}{|c|l|c|}
\hline 7 & Karamunting & Akar \\
\hline 8 & Kecabling & Akar \\
\hline 9 & Kratau & Akar \\
\hline 10 & Kujajing & Akar \\
\hline 11 & Kumis kucing & Akar \\
\hline 12 & Langsat & Akar \\
\hline 13 & Mambung & Akar \\
\hline 14 & Panawar seribu & Akar \\
\hline 15 & Pasak bumi & Akar \\
\hline 16 & Pirawas & Akar \\
\hline 17 & Pasak bumi & Akar \\
\hline 18 & Pirawas & Akar \\
\hline 19 & Rotan nyame & Akar \\
\hline 20 & Sungkai & Akar \\
\hline 21 & Tambura & Akar \\
\hline 22 & Tangkuhis & Akar \\
\hline 23 & Tingen & Akar \\
\hline
\end{tabular}

Dari 40 leksikon jenis tumbuhan obat yang digunakan suku Dayak Bakumpai sebagai pengobatan tradisional maka terdapat 23 leksikon jenis tumbuhan obat yang memanfaatkan bagian akar sebagai pengobatan tradisional.

Tabel 3

Leksikon Tumbuhan Obat Berdasarkan Bagian Batang yang Dimanfaatkan

\begin{tabular}{|c|l|l|}
\hline No & \multicolumn{1}{|c|}{ Nama Tumbuhan } & \multicolumn{1}{c|}{ Bagian yang di Manfaatkan } \\
\hline 1 & Akar kuning & Batang \\
\hline 2 & Kayu baru & Batang \\
\hline
\end{tabular}

Dari 40 leksikon jenis tumbuhan obat yang digunakan suku Dayak Bakumpai sebagai pengobatan tradisional maka terdapat 2 leksikon jenis tumbuhan obat yang memanfaatkan bagian batang sebagai pengobatan tradisional.

Tabel 4

Leksikon Tumbuhan Obat Berdasarkan Bagian Daun yang Dimanfaatkan

\begin{tabular}{|c|l|c|}
\hline No & \multicolumn{1}{|c|}{ Nama Tumbuhan } & Bagian yang di Manfaatkan \\
\hline 1 & Bingkudu hutan & Daun \\
\hline 2 & Hambin buah & Daun \\
\hline 3 & Kakabat biru & Daun \\
\hline 4 & Kusuma indrat & Daun \\
\hline 5 & Laus & Daun \\
\hline 6 & Patah kemudi & Daun \\
\hline 7 & Pikis bidadari & Daun \\
\hline 8 & Pucuk putat & Daun \\
\hline 9 & Sangkariho & Daun \\
\hline 10 & Sarai & Daun \\
\hline 11 & Sirih & Daun \\
\hline 12 & Tuntung uhat & Daun \\
\hline
\end{tabular}


Tuah Talino

Tahun XIII Volume 13 Nomor 1 Edisi 5 Juli 2019

ISSN 0216-079X

Balai Bahasa Kalimantan Barat

Dari 40 leksikon jenis tumbuhan obat yang digunakan suku Dayak Bakumpai sebagai pengobatan tradisional maka terdapat 12 leksikon jenis tumbuhan obat yang memanfaatkan bagian daun sebagai pengobatan tradisional.

Tabel 5

Leksikon Tumbuhan Obat Berdasarkan Bagian Kulit Kayu yang Dimanfaatkan

\begin{tabular}{|c|l|c|}
\hline No & \multicolumn{1}{|c|}{ Nama Tumbuhan } & Bagian yang di Manfaatkan \\
\hline 1 & Kayu muhur & Kulit kayu \\
\hline 2 & Papulut & Kulit kayu \\
\hline
\end{tabular}

Dari 40 leksikon jenis tumbuhan obat yang digunakan suku Dayak Bakumpai sebagai pengobatan tradisional maka terdapat 2 leksikon jenis tumbuhan obat yang memanfaatkan bagian kulit kayu sebagai pengobatan tradisional.

Tabel 6

Leksikon Tumbuhan Obat Berdasarkan Bagian Umbi atau Rimpang yang Dimanfaatkan

\begin{tabular}{|c|l|c|}
\hline No & \multicolumn{1}{|c|}{ Nama Tumbuhan } & Bagian yang di Manfaatkan \\
\hline 1 & Janar kuning & umbi atau rimpang \\
\hline 2 & Janar putih & umbi atau rimpang \\
\hline
\end{tabular}

Dari 40 leksikon jenis tumbuhan obat yang digunakan suku Dayak Bakumpai sebagai pengobatan tradisional maka terdapat 2 leksikon jenis tumbuhan obat yang memanfaatkan bagian umbi atau rimpang sebagai pengobatan tradisional.

Tabel 7

Leksikon Tumbuhan Obat Berdasarkan Bagian Pucuk Daun yang Dimanfaatkan

\begin{tabular}{|c|c|c|}
\hline No & Nama Tumbuhan & Bagian yang di Manfaatkan \\
\hline 1 & Sabambelum & Pucuk daun \\
\hline
\end{tabular}

Dari 40 leksikon jenis tumbuhan obat yang digunakan suku Dayak Bakumpai sebagai pengobatan tradisional terdapat hanya satu leksikon jenis tumbuhan obat yang memanfaatkan bagian pucuk daun sebagai pengobatan tradisional.

\section{Teknik Peramuan Tumbuhan Obat Suku Dayak Bakumpai}

Berdasarkan hasil temuan di lapangan, bagian tumbuhan yang digunakan untuk pengobatan berbeda-beda antarspesies tumbuhan dan tergantung jenis penyakit yang akan diobati. Cara pengobatan tradisional suku Dayak Bakumpai dilakukan dengan cara diminum, dioles, diusap, ditempel, diuapkan, dan disiram ke bagian tubuh (mandi).

Tabel 8

Nama Tumbuhan Obat Berdasarkan Teknik Peramuan

\begin{tabular}{|c|l|l|}
\hline No & Nama Tumbuhan & \multicolumn{1}{c|}{ Teknik Peramuan dan Nilai Pengetahuan } \\
\hline 1 & Akar kuning & $\begin{array}{l}\text { Batang diiris tipis-tipis secukupnya kemudian direbus } \\
\text { dengan air putih sampai mendidih. Selanjutnya diminum } \\
\text { secara rutin dua kali sehari. }\end{array}$ \\
\hline 2 & Akar melati & $\begin{array}{l}\text { Akar direndam dengan air putih secukupnya, kemudian } \\
\text { diminum setiap hari berturut-turut. }\end{array}$ \\
\hline
\end{tabular}


Tuah Talino

Tahun XIII Volume 13 Nomor 1 Edisi 5 Juli 2019

ISSN 0216-079X

Balai Bahasa Kalimantan Barat

\begin{tabular}{|c|c|c|}
\hline 3 & Akar pudak & $\begin{array}{l}\text { Akar direbus dengan air dan airnya diminum setiap hari } \\
\text { berturut-turut. }\end{array}$ \\
\hline 4 & Belimbing tunjuk & $\begin{array}{l}\text { Akar belimbing tunjuk, akarmambung, akar hapa-hapa, } \\
\text { akar kecabling, akarkumis kucing, dan akartingen } \\
\text { dicampur jadi satu kemudian direndam atau direbus } \\
\text { dengan air. Setelah itu diminum setiap hari. }\end{array}$ \\
\hline 5 & Bingkudu hutan & $\begin{array}{l}\text { Sepuluh lembar daun bingkudu hutan, sepuluh lembar } \\
\text { daun sarai, lima lembar daun laus direbus sampai } \\
\text { mendidih kemudian campurkan air dingin secukupnya } \\
\text { hingga air menjadi hangat. Setelah itu, air tersebut } \\
\text { digunakan untuk mandi pada pagi hari. }\end{array}$ \\
\hline 6 & Hambin buah & $\begin{array}{l}\text { Daun dihaluskan kemudian diperas dan diambil airnya. } \\
\text { Selanjutnya, setiap hari diminumkan kepada anak kecil. }\end{array}$ \\
\hline 7 & Hapa-hapa & $\begin{array}{l}\text { Akar hapa-hapa dan akar mambung direndam dengan air } \\
\text { putih. Kemudian, diminum setiap hari. }\end{array}$ \\
\hline 8 & Hara & $\begin{array}{l}\text { Akar hara, akar kratau, dan akar kujajing direndam } \\
\text { dengan air putih kemudian diminum tiga kali sehari selama } \\
\text { tiga bulan. }\end{array}$ \\
\hline 9 & Jajuluk langit & Akar direndam dengan air putih dan diminum. \\
\hline 10 & Janar kuning & $\begin{array}{l}\text { Umbi atau rimpang dihaluskan kemudian diperas dan } \\
\text { diambil airnya. Setelah itu airnya diminum setiap hari. }\end{array}$ \\
\hline 11 & Janar putih & $\begin{array}{l}\text { Diparut sampai halus kemudian ambil airnya dan setiap } \\
\text { hari diminum dua kali sehari. }\end{array}$ \\
\hline 12 & Kakabat biru & $\begin{array}{l}\text { Lima lembar daun dihaluskan kemudian diperas dan } \\
\text { diambil airnya. Setelah itu diminum setiap hari. }\end{array}$ \\
\hline 13 & Karamunting & $\begin{array}{l}\text { Akar direndam dengan air putih secukupnya kemudian } \\
\text { diminum setiap. }\end{array}$ \\
\hline 14 & Kayu baru & $\begin{array}{l}\text { Batang dikerik lalu dicampur dengan bedak secukupnya. } \\
\text { Kemudian setelah mandi dioleskan pada bagian perut. }\end{array}$ \\
\hline 15 & Kayи muhur & $\begin{array}{l}\text { Kulit kayu muhur direbus kemudian diambil airnya dan } \\
\text { diminum. }\end{array}$ \\
\hline 16 & Kecabling & $\begin{array}{l}\text { Akar kecabling, belimbing tunjuk, akar mambung, akar } \\
\text { hapa-hapa, akar kumis kucing, dan akar tingen dicampur } \\
\text { jadi satu kemudian direndam atau direbus dengan air. } \\
\text { Setelah itu diminum setiap hari. }\end{array}$ \\
\hline 17 & Kratau & $\begin{array}{l}\text { Akar kratau, akar hara, dan akar kujajing direndam } \\
\text { dengan air putih kemudian diminum tiga kali sehari selama } \\
\text { tiga bulan. }\end{array}$ \\
\hline 18 & Kujajing & $\begin{array}{l}\text { Akar kujajing, akar hara, dan akar kratau direndam } \\
\text { dengan air putih kemudian diminum tiga kali sehari selama } \\
\text { tiga bulan. }\end{array}$ \\
\hline 19 & Kumis kucing & $\begin{array}{l}\text { Akar kumis kucing, akar kecabling, belimbing tunjuk, akar } \\
\text { mambung, akar hapa-hapa, dan akar tingen dicampur jadi } \\
\text { satu kemudian direndam atau direbus dengan air. Setelah } \\
\text { itu diminum setiap hari. }\end{array}$ \\
\hline 20 & Kusuma indrat & $\begin{array}{l}\text { Lima lembar daun dihaluskan kemudian dibuat bedak. } \\
\text { Setelah itu dioleskan pada bagian perut. }\end{array}$ \\
\hline 21 & Langsat & $\begin{array}{l}\text { Akar direndam dengan air secukupnya. Kemudian } \\
\text { diminum setiap hari. }\end{array}$ \\
\hline 22 & Laus & Lima lembar daun laus, sepuluh lembar daun bingkudu \\
\hline
\end{tabular}




\begin{tabular}{|c|c|c|}
\hline & & $\begin{array}{l}\text { hutan, dan sepuluh lembar daun sarai direbus sampai } \\
\text { mendidih kemudian campurkan air dingin secukupnaa } \\
\text { hingga air menjadi hangat. Setelah itu, air tersebut } \\
\text { digunakan untuk mandi pada pagi hari. }\end{array}$ \\
\hline 23 & Mambung & $\begin{array}{l}\text { Akar mambung dan akar hapa-hapa direndam dengan air } \\
\text { putih. Kemudian, diminum setiap hari. }\end{array}$ \\
\hline 24 & Panawar seribu & $\begin{array}{l}\text { Akar direbus dengan air sebanyaknya kemudian air } \\
\text { tersebut digunakan untuk mandi. }\end{array}$ \\
\hline 25 & Papulut & $\begin{array}{l}\text { Bagian kulit dikikis secukupnya kemudian ditempelkan } \\
\text { pada bagian gigi yang sakit. }\end{array}$ \\
\hline 26 & Pasak bumi & $\begin{array}{l}\text { Akar direndam seharian dengan air putih kemudian } \\
\text { diminum setiap hari. }\end{array}$ \\
\hline 27 & Patah kemudi & $\begin{array}{l}\text { Daun dihaluskan kemudian dibuat untalan (pil) dan } \\
\text { diminum setiap hari. }\end{array}$ \\
\hline 28 & Pikis bidadari & $\begin{array}{l}\text { Daun dihaluskan dan dibuat bedak. Kemudian diusapkan } \\
\text { ke wajah. }\end{array}$ \\
\hline 29 & Pirawas & $\begin{array}{l}\text { Akar direndam dengan air putih. Kemudian diminum } \\
\text { setiap hari setelah melahirkan. }\end{array}$ \\
\hline 30 & Pucuk putat & $\begin{array}{l}\text { Daun dihaluskan kemudian dioleskan pada bagian tubuh } \\
\text { yang gatal. }\end{array}$ \\
\hline 31 & Rotan nyame & $\begin{array}{l}\text { Akar direndam dengan air putih secukupnya kemudian } \\
\text { diminum setiap hari. }\end{array}$ \\
\hline 32 & Sabambelum & $\begin{array}{l}\text { Pucuk daun dihaluskan kemudian dibuat bedak dan } \\
\text { dioleskan pada tubuh anak. }\end{array}$ \\
\hline 33 & Sangkariho & $\begin{array}{l}\text { Sepuluh lembar daun sangkariho dihaluskan kemudian } \\
\text { diperas dan diambil airnya. Setelah itu diminum setiap hari } \\
\text { setelah melahirkan. }\end{array}$ \\
\hline 34 & Sarai & $\begin{array}{l}\text { Sepuluh lembar daun sarai, sepuluh lembar daun bingkudu } \\
\text { hutan, dan lima lembar daun laus direbus sampai } \\
\text { mendidih kemudian campurkan air dingin secukupnya } \\
\text { hingga air menjadi hangat. Setelah itu, air tersebut } \\
\text { digunakan untuk mandi pada pagi hari. }\end{array}$ \\
\hline 35 & Sirih & $\begin{array}{l}\text { Rebus lima hingga sepuluh lembar daun sirih dengan dua } \\
\text { hingga lima gelas air putih dan diminum, kemudian air } \\
\text { hasil rebusan bisa diuapkan atau disiramkan pada alat } \\
\text { kelamin perempuan yang mengalami keputihan, } \\
\text { pendarahan, dan bau badan. }\end{array}$ \\
\hline 36 & Sungkai & $\begin{array}{l}\text { Akar direndam dengan air secukupnya kemudian diminum } \\
\text { setiap hari. }\end{array}$ \\
\hline 37 & Tambura & $\begin{array}{l}\text { Akar direndam dengan air secukupnya kemudian diminum } \\
\text { setiap hari setelah melahirkan. }\end{array}$ \\
\hline 38 & Tangkuhis & $\begin{array}{l}\text { Akar direbus dengan air secukupnya kemudian diminum } \\
\text { tiga kali sehari. }\end{array}$ \\
\hline 39 & Tingen & $\begin{array}{l}\text { Akar tingen, akar kumis kucing, akar kecabling, belimbing } \\
\text { tunjuk, akar mambung, dan akar hapa-hapa dicampur jadi } \\
\text { satu kemudian direndam atau direbus dengan air. Setelah } \\
\text { itu diminum setiap hari. }\end{array}$ \\
\hline 40 & Tuntung uhat & $\begin{array}{l}\text { Tujuh lembar daun dihaluskan atau diremas-remas sampai } \\
\text { halus. Kemudian dioleskan pada bagian luka. }\end{array}$ \\
\hline
\end{tabular}


Dengan demikian, suku Dayak Bakumpai masih mempercayai sistem pengobatan tradisional. Setiap tumbuhan yang digunakan sebagai obat tradisional memiliki fungsi dan teknik peramuan dalam pengobatan yang berbeda-beda. Ada tumbuhan yang dapat diramu dan dicampur untuk menghasilkan obat, tetapi ada pula tumbuhan yang memiliki fungsi pengobatan tersendiri. Begitu pula dengan proses atau cara pengobatannya, ada tumbuhan yang harus dicampur dengan tumbuhan lain dan ada pula yang tidak. Hal ini menunjukkan kekayaan warisan leluhur suku Dayak Bakumpai di Kalimantan Selatan berupa keragaman leksikon etnomedisin dan teknik peramuan dalam pengobatan tradisional.

Leksikon etnomedisin dalam teknik peracikan tumbuhan obat suku Dayak Bakumpai, yakni diminum, dioles, diusap, ditempel, diuapkan, dan disiram ke bagian tubuh (mandi). Pengobatan dengan diminum dengan cara direndam dengan air putih secukupnya atau direbus dengan air putih sampai mendidih. Ada juga diparut sampai halus kemudian diambil airnya dan setiap hari diminum dua kali sehari. Daun ada juga yang dihaluskan kemudian diperas dan diambil airnya serta bagian daun yang dihaluskan kemudian dibuat untalan (pil) dan diminum setiap hari.

Teknik peracikan dengan dioles dilakukan dengan batang dikerik lalu dicampur dengan bedak secukupnya. Kemudian, setelah mandi dioleskan pada bagian perut. Bagian tumbuhan pucuk daun dihaluskan kemudian dibuat bedak dan dioleskan pada tubuh anak. Cara penggunaan dengan diusap, yakni bagian daun dihaluskan dan dibuat bedak lalu diusapkan ke wajah. Cara penggunaan dengan ditempel, yakni dengan teknik peracikan bagian kulit dikikis secukupnya kemudian ditempelkan pada bagian yang sakit. Selanjutnya, pengobatan dengan disiram, yakni dengan peracikan air hasil rebusan yang diuapkan atau disiramkan pada bagian tubuh. Dengan demikian, dapat dikatakan bahwa teknik peramuan tumbuhan obat yang digunakan suku Dayak Bakumpai berkaitan dengan nilai budaya dari kehidupan suku Dayak Bakumpai itu sendiri.

Jadi, salah satu suku di Kalimantan Selatan yang masih memanfaatkan pengetahuan tumbuhan sebagai pengobatan adalah suku Dayak Bakumpai. Penelitian mengenai leksikon etnomedisin ini mampu menggali pengetahuan dasar terhadap pengembangan kosakata tumbuhan obat. Selain itu, pengetahuan leksikon etnomedisin tumbuhan obat juga menjadi bentuk kearifan lokal suku Dayak Bakumpai di Kalimantan Selatan.

\section{PENUTUP}

\section{Simpulan}

Berdasarkan hasil analisis leksikon etnomedisin dalam pengobatan tradisional suku Dayak Bakumpai ditemukan 40 leksikon etnomedisin dalam pengobatan tradisional suku Dayak Bakumpai. Dari 40 leksikon jenis tumbuhan obat yang digunakan suku Dayak Bakumpai dapat diklasifikasikan lagi menjadi 6 bagian, yakni tumbuhan obat berdasarkan, yaitu: (1) bagian akar yang dimanfaatkan, (2) bagian batang yang dimanfaatkan, (3) bagian daun yang dimanfaatkan, (4) bagian kulit kayu yang dimanfaatkan, (5) bagian umbi atau rimpang yang dimanfaatkan, dan (6) bagian pucuk daun yang dimanfaatkan. 
Tuah Talino

Tahun XIII Volume 13 Nomor 1 Edisi 5 Juli 2019

ISSN 0216-079X

Balai Bahasa Kalimantan Barat

Kemudian, bagian tumbuhan yang digunakan untuk pengobatan, yakni akar, umbi (rimpang), batang, daun, pucuk, dan bagian kulit tumbuhan. Selanjutnya, teknik peracikan tumbuhan obat tradisional suku Dayak Bakumpai dilakukan dengan cara diminum, dioles, diusap, ditempel, diuapkan, dan disiram ke bagian tubuh (mandi).

Kekayaan kosakata tumbuhan obat memiliki kedekatan dengan alam lingkungannya. Hal ini mengingat suku Dayak Bakumpai sangat akrab dengan alam. Banyak aktivitas yang dilakukan terkait dengan lingkungan hutan. Di samping itu, dengan adanya praktik pengobatan secara tidak langsung kosakata tumbuhan obat akan terekam dan tertransmisikan. Tentunya, hal ini akan menambah kekayaan kosakata tumbuhan obat dalam bahasa suku Dayak Bakumpai.

Saran

Hasil penelitian ini dapat dijadikan salah satu acuan untuk penelitian lanjutan, terutama penelitian yang terkait dengan leksikon etnomedisin. Selain itu, penelitian leksikon etnomedisin pengobatan tradisional ini dapat dilanjutkan dan dikembangkan lebih mendalam lagi dengan fokus kajian yang berbeda, seperti proses dan cara pengobatan selain menggunakan tumbuhan berkhasiat obat.

\section{DAFTAR PUSTAKA}

Aisyah, dkk. (2018). Leksikon Nama Penyakit dan Pengobatan Tradisional dalam Bahasa Melayu Dialek Pontianak di Kecamatan Kubu. Untan, 7(3), 1-8.

Almos, R dan Pramono. (2015). Leksikon Etnomedisin dalam Pengobatan Tradisional Minangkabau. Arbiter, 2(1), 44-53.

Budhiono, R. H. (2017). Leksikon Alat dan Aktivitas Bertanam Padi dalam Bahasa Jawa. Kandai, 13(2), 235-248.

Chaer, Abdul. (2007). Leksikologi dan Leksikografi Indonesia. Jakarta: Rineka Cipta.

Djajasudarma, Fatimah. (2010). Metode Linguistik: Ancangan Metode Penelitian dan Kajian. Bandung: Refika Aditama.

Fitri, dkk. (2018). Eksplorasi Pengetahuan Obat Tradisional dalam Presfektif Hukum Kekayaan Intelektual di Bengkulu. Mimbar Hukum, 30(2), 304-315.

Foster, M.G \& Barbara, G. (2015). Antropologi Kesehatan. Jakarta: Universitas Indonesia.

Hestiyana. (2017). Leksikon dalam Tuturan Mantra Panawar (Kajian Etnomedisin sebagai Alternatif Pengobatan Tradisional Masyarakat Banjar).

Prosiding Membaca Nusantara melalui Bahasa, Media, dan Pembelajarannya, 351-361. Yogyakarta: UNY.

Humaedi, M. Alie. (2016). Etnografi Pengobatan Praktik Budaya Peramuan dan Sugesti Komunitas Adat Tau Taa Vana. Yogyakarta: Lkis.

Kridalaksana, Harimurti. (2011). Kamus Linguistik. Jakarta: Gramedia Pustaka Utama.

Mahsun, M.S. (2013). Metode Penelitian Bahasa: Tahapan Strategi, Metode, dan Tekniknya. Jakarta: RajaGrafindo Persada. 
Mulyanti. (2016). Latar Belakang Pemilihan Pengobatan Tradisional pada Masyarakat di Desa Rantau Panjang Kiri Hilir Kecamatan Kubu Babussalam Kabupaten Rokan Hilir. JOM FISIP, 3(2), 1-15.

Novianti, Evi. (2018). Medan Makna Verba Melihat dalam Bahasa Melayu Sanggau. Tuah Malino, 13(2), 25-36.

Nurkosim. (2009). Rahasia Habbatussauda Sunah dalam Formulasi Herbal. Bandung: Simbiosa Rekatama Media.

Purwanto. (2002). Studi Etnomedisinal dan Fitofarmakope Tradisional Indonesia. Prosiding Seminar Nasional II Tumbuhan Obat dan Aromatik. Bogor: LIPI, 96-109.

Sudaryanto. (2015). Metode dan Aneka Teknik Analisis Bahasa Pengantar Penelitian Wahana Kebudayaan secara Linguistis. Yogyakarta: Sanata Dharma University Press.

Sugiyono. (2014). Memahami Penelitian Kualitatif. Bandung: Alfabeta.

Suktiningsih. (2016). Leksikon Fauna Masyarakat Sunda: Kajian Ekolinguistik. Retorika, 2(1), 138-156.

Suparni, Ari Wulandari. (2013). Manfaat dan Khasiat Sehat dari Dapur. Yogyakarta: Andi Offset.

Wasito, Hendri. (2011). Obat Tradisional Kekayaan Indonesia. Yogyakarta: Graha Ilmu.

Wijana, I Dewa Putu dan M. Rohmadi. (2011). Semantik Teori dan Analisis. Surakarta: Yuma Pustaka.

Wijana, I Dewa Putu. (2015). Pengantar Semantik Bahasa Indonesia. Yogyakarta: Pustaka Pelajar.

Wulandari, Ari. (2018). Eksplorasi Pengetahuan Lokal Etnomedisin dan Tumbuhan Obat di Desa Pagar Dalam, Pelita Jaya, Tanjung Raya dan Ulok Manek Kecamatan Pesisir Selatan Kabupaten Pesisir Barat. Skripsi. Fakultas Tarbiyah dan Keguruan Universitas Islam Negeri Raden Intan Lampung. 